pedagogical sciences, associate professor of the department of natural sciences and methods of their teaching of Volodymyr Vynnychenko Central Ukrainian State Pedagogical University.
Circle of research interests: the issues of training future science teachers, professional development of future teachers.

УДК 372.862

DOI: 10.36550/2415-7988-2019-1-183-143-145

Стаття надійшла до редакиії 13.11.2019 p.

\author{
ПУлЯк Ольга Василівна - \\ кандидат педагогічних наук, доцент, \\ доцент кафедри теорії та методики технологічної підготовки, \\ охорони праці та безпеки життєдіяльності \\ Центральноукраїнського державного педагогічного університету \\ імені Володимира Винниченка \\ ORCID:https://orcid.org/0000-0002-7061-5620 \\ e-mail: olapuliak@gmail.com
}

\begin{abstract}
Постановка та обгрунтування актуальності проблеми. Сучасне суспільство характеризується якісно новими тенденціями розвитку в інформаційно-комунікаційній сфері, в першу чергу стрімким формуванням глобального інформаційного освітнього простору та глобальним інформаційним протиборством, розробкою i використанням новітніх Інтернет технологій, виникненням принципово нових суспільних відносин за різноманітними напрямами інформаційної діяльності.
\end{abstract}

Поширення інформаційних технологій та засобів їх реалізації привело до створення універсального комунікаційно-інформаційного середовища - мережевого спілкування (Інтернет, мобільний зв'язок, аудіо та відео форми, онлайнзустрічі тощо), яке, крім користі (розширення меж пізнання навколишнього світу, копіювання нових технологій, віртуального «входження» в різноманітні сфери), уможливлює маніпулювання інформацією, вплив на поведінку учасників освітнього процесу та їхню дезорієнтацію місця i ролі в суспільстві, негативний психологічний вплив на особистість. Інформаційна культура особистості, як засіб іiі соціалізації в глобальному інформаційному суспільстві, має сприяти комфортному та безпечному перебуванню в мережі спілкування, адекватній оцінці інформаційних потоків, орієнтувати на безпечне користування сучасними засобами комунікації.

Аналіз останніх досліджень і публікацій. Питання становлення i розвитку інформаційної культури особистості учня, його інформаційної підготовки у закладах освіти та діяльності засобами інформатизації займають особливе місце в дослідженнях вітчизняних та зарубіжних авторів. Аналіз дослідження проблеми формування інформаційної культури в шкільному освітньому процесі за останні роки набуває дуже важливого значення. Цією проблемою займалися вчені: М. Близнюк, І. Бургун, М. Жалдак, В. Мадзігон, O. Малишевський, Б. Оранюк, Г. Терещук, А. Ясінський та інші.
Результати аналізу науково-методичної літератури дають підстави стверджувати, що сучасні підходи до формування інформаційної культури учнів обумовлені запитом суспільства на розвиток особистостей 3 високою інформаційною культурою і необхідністю системної соціально-освітньої протидії маніпулюванням свідомістю та психікою підлітків за допомогою інформаційних засобів.

Мета статті - проаналізувати сучасний стан, проблеми та способи створення освітнього середовища, яке уможливлює формування інформаційної культури учнів у мережевому спілкуванні.

Виклад основного матеріалу дослідження. Інформаційна культура особистості передбачає формування необхідних знань, ціннісних орієнтації, компетентностей роботи з інформацією, оволодіння нормами і правилами поведінки в інформаційному середовищі. Поняття інформаційної культури, вживається також в контексті культури безпеки, захисту від агресії, та розглядається як соціальний феномен, який входить в культуру суспільства у контексті ії етично-безпекового компонента [2].

За даними Інтернет Асоціації України 65\% населення України - регулярні користувачі Інтернету. А за даними звіту ЮНІСЕФ «Дитина в цифровому світі» один із трьох користувачів Інтернету в світі - дитина. Кількість користувачів мережі щоденно зростає. Інтернет стрімко розвивається. Тому світ постійно потребує додаткових гарантій, щоб забезпечити права людини в умовах цифрової ери [3].

Оскільки вхід кожної людини в інформаційнокомунікаційне середовище $є$ легкодоступним, то агресивно налаштовані особи можуть маніпулювати інформацією, яка для споживача інформації стає агресивною та небезпечною. Відповідно на перший план виходить проблема захисту людини від негативної інформації [1]. В зв'язку з чим, однією із основних завдань освіти стає формування інформаційної культури особистості в контексті ії роботи $з$ інформацією, оскільки однією 3 функцій 
культури $є$ захист особистості від негативного впливу інформації.

У звіті ЮНІСЕФ «Діти в цифровому світі» рекомендовано навчати дітей «контролювати їхні налаштування конфіденційності, щоб захистити особисту інформацію, ім'я, дату народження, адресу, друзів, сім'ю, школу й особисті фотографії. А також навчитися виявляти небезпеку. Адже публікація такої інформації може призвести до крадіжки особистих даних. А вони можуть бути основою для інших ризиків».

У Рекомендації Комітету Міністрів Ради Свропи щодо Керівництва з дотримання, захисту та реалізації прав дитини в цифровому середовищі зазначається: «Держави повинні поважати, захищати та реалізовувати право дитини на приватність та захист даних. Забезпечувати, щоб відповідні зацікавлені сторони були обізнані та поважали право дитини на конфіденційність та захист даних. До таких сторін належать, зокрема, ті, хто обробляє особисті дані. А також однолітки дитини, батьки чи опікуни та педагоги» [4].

Втілення положень міжнародних документів відображено і у національному законодавстві. Ідею поваги прав людини в Інтернеті можна знайти в Національному плані дій щодо реалізації Конвенції ООН про права дитини на період до 2021 року. [5] Один із пріоритетів цього плану - створення безпечного інформаційного простору для дітей. Зокрема, завдяки забезпеченню захисту персональних даних дитини, іншої конфіденційної інформації про неї, а також - гарантуванню безпеки дітей в інформаційному просторі.

Онлайновий освітній інформаційний простір закладу освіти, як правило, складається 3 таких елементів: сайт; сторінка або група закладу у соціальній мережі; сторінки вчителів та адміністрації шкіл у соціальній мережі; текстові або відео-блоги вчителів; канал закладу освіти на Youtube; сторінка закладу освіти на сайті «Інформаційна система управління освітою України» та інших. Але, нажаль інформаційний простір закладу освіти України може порушувати права дитини на приватність.

У травні-липні 2018 року Громадська організація «Центр кращого Інтернету» та Державна наукова установа «Інститут модернізації змісту освіти» за підтримки «Counterpart International» та USAID провели в Україні дослідження «Повага та безпека: моніторинг сайтів закладів освіти». За його результатами:

- кожний сьомий сайт містить фото дитини та зазначення класу;

- кожний п'ятий сайт - фото та прізвище, ім'я, по батькові;

- на 1 зі 100 сайтів ідентифіковано прізвище, ім'я, по батькові, домашню адресу та дату народження дітей, зарахованих до 1 класу;

- майже на всіх досліджених сайтах - відсутня інформація про те, до кого можна звернутися для видалення персональних даних дитини з сайту;

- 6 iз 100 сайтів закладів освіти не оновлюються протягом року та більше, але їхній зміст залишається доступним;

- майже на кожному четвертому 3 них заклади освіти зазначають, що мають новий сайт та зазначають посилання на нього [3].

Щоб не допустити таких порушень, фахівці рекомендують:

1. Уважно ставитися до публікації матеріалів в Інтернеті чи надсилання будь-якої персональної інформації електронною поштою. Наприклад, у методичний відділ чи до громадської організації. Враховуйте чинне законодавство та зважайте на «Правило 4Б»: Інформація, розміщена у відкритому доступі в Інтернеті, є доступною:

- Будь-де;

- Будь-кому;

- Будь-коли;

- і може бути використана з Будь-якою метою.

2. Перевіряти, чи поважають права людини та захищають іiі персональні дані в Інтернеті. Наприклад: на сайті та сторінці вашого закладу в соціальних мережах, блогах вчителів. Для перевірки - використовуйте перелік питань, за яким можна проаналізувати діяльність закладу освіти щодо реалізації та захисту прав людини в Інтернеті.

3. Запроваджувати власні правила конфіденційності та поваги прав людини на сайті закладу освіти та на сторінках у соціальних мережах. Щоб обговорити та розробити такі правила, запросіть адміністрацію вашого закладу, вчителів, батьків та учнівство [3].

Отже, потрібно створити інформаційний простір закладу освіти, який не порушує прав людини. Сьогодні Інтернет надає багато можливостей для реалізації прав людини. Важливо знаходити баланс між ними та захистом прав усіх учасників освітнього процесу.

Тому саме цілісний та безпечний освітній процес (органічним складником якого є виховання інформаційної культури) забезпечує готовність учнів протистояти впливу небезпек інформаційного середовища. Крім того такий освітній процес сприяє позитивним змінам в особистості школярів навіть під впливом деструктивних факторів.

Аналіз особливостей методів проведення занять 3 формування інформаційної культури показав, що їх необхідно проводити у відповідності до особливостей шкільного віку Та для цього спочатку вчитель сам повинен оволодіти способами виявляти інформаційну загрозу, вміти користуватися сучасними засобами комунікації i технологіями, протидіяти їй, а потім передати свій досвід учням через систему формування в компетентностей виявляти інформаційну загрозу, перевірити дієвість своїх компетентностей на окремому занятті. Вчитель обов'язково повинен оволодіти цілою системою занять 3 формування компетентностей виявляти інформаційну загрозу в мережевому спілкуванні, використовувати міжпредметні зв'язки, забезпечити зв'язок 3 позакласною роботою, адже перебування учня в мережевому спілкуванні переважно відбувається 
саме поза освітнім середовищем.

Наше спілкування 3 учителями, виявили що вони, нажаль, недостатньо володіють знаннями проблеми кібербулінгу, інформаційної безпеки особистості, інформаційної загрози в мережевому спілкуванні, не досить добре володіють засобами комунікації.

Інтерв'ювання вчителів та старшокласників показали, що учні частіше користуються Інтернетом, ніж викладачі.

Для вчителів в більшості випадків Інтернет позиціонується як база даних, яка допомагає готуватися до уроків. I тільки половина опитаних вчителів, використовуе Інтернет як засіб комунікації між друзями i пізнання нових технологій. У той час як більша частина учнів, використовують Інтернет як базу даних для навчання, i майже всі - для мережевого спілкування.

Старшокласники в інформаційних засобах (особливо смартфон, планшет) вбачають засіб спілкування, можливість зафіксувати подію, селфі (можливості фото, відео), бути в курсі всіх подій, переслати товаришам цікаве відео, фото, отримати лайки, пораду тощо.

Вчителі ж, в своїй більшості, розуміють можливості передачі через мобільні засоби неконтрольованої небезпечної інформації різного змісту.

Тобто, спостерігається суттєва різниця в поглядах вчителів i підлітків на сучасні комунікаційні можливості засобів зв'язку і мережі спілкування.

Отже, наразі необхідно проводити роботу з навчання учителів формуванню інформаційної культури учнів у мережевому спілкуванні необхідно організувати в різних формах. Це можуть бути семінари, конференції, вебінари, тренінги тощо.

Висновки та перспективи подальших розвідок напряму. Аналіз освітнього процесу показав, що заклади загальної середньої освіти впливають на важливі соціальні фактори становлення інформаційної культури учнів.

Поряд 3 тим, наявність сучасних інформаційних технологій, мережевого спілкування привели до появи небезпечних факторів соціалізації (інтернет, мобільні телефони, комп'ютерні ігри, ЗМI тощо), на які навчальний заклад не може вплинути. Заклад загальної середньої освіти впливає не стільки на ці соціальні фактори, скільки на процес взаємодії школярів із цими негативними факторами соціалізації.

Наразі дуже важливим $є$ навчання учителів формуванню інформаційної культури учнів у мережевому спілкуванні та створенню безпечного онлайногового простору навчального закладу для всіх учасників освітнього процесу.

\section{СПИСОК ДЖЕРЕЛ}

1. Кулик Є. М. Безпечний та привітний веб-простір / Є. М. Кулик // Педагогіка толерантності. - 2010. - № 34. - C. $70-78$.

2. Оранюк Б. Ю. Педагогічні умови формування інформаційної культури учнів у мережевому спілкуванні / Б. Ю. Оранюк // Педагогічний альманах. Збірник наукових праць. - Випуск 29. - Херсон : Видавництво КВНЗ «Херсонська академія неперервної освіти», 2016. C. $40-46$.

3. Права людини в освітньому просторі. 3.2.1. Права людини та Інтернет EDERA_OSCT: HRE101 URL:

https://drive.google.com/drive/folders/1GyjQPJYRgGjDfkmapz-R8DL7_iI-EP- (дата звернення: 10.10.2019)

4. Посібник 3 прав людини для Інтернеткористувачів та пояснювальний меморандум - Київ : Інжиніринг, 2015. - 56 с.

5. Постанова КМУ Про затвердження Державної соціальної програми "Національний план дій щодо реалізації Конвенції ООН про права дитини" на період до 2021 року. - URL: https://zakon.rada.gov.ua/laws/main/4532018-\%D0\%BF (дата звернення: 10.10.2019)

\section{REFERENCES}

1. Kulyk, YE.M. (2010) Bezpechnyy ta pryvitnyy vebprostir [Secure and friendly web space] Kyiv.

2. Oranyuk B.YU. (2016) Pedahohichni umovy formuvannya informatsiynoyi kul'tury uchniv u merezhevomu spilkuvanni [Pedagogical conditions of formation of information culture of pupils in network communication] Kherson

3. Prava lyudyny v osvitn'omu prostori. 3.2.1. Prava lyudyny ta Internet (2018) [Human rights in the educational space. 3.2.1. Human rights and the Internet] Kyiv.

4. Posibnyk z prav lyudyny dlya Internet-korystuvachiv ta poyasnyuval'nyy memorandum (2016) [Human rights Handbook for Internet users and explanatory Memorandum] Kyiv.

5. Postanova KMU (2018) Pro zatverdzhennya Derzhavnoyi sotsial'noyi prohramy "Natsional'nyy plan diy shchodo realizatsiyi Konventsiyi OON pro prava dytyny» na period do $2021 \mathrm{roku}$. [On approval of the state social program «national action plan for the implementation of the UN Convention on the rights of the child» for the period up to 2021.] Kyiv.

\section{ВЈДОМОСТІ ПРО АВТОРА}

ПУЛЯк Ольга Василівна - кандидат педагогічних наук, доцент, доцент кафедри теорії i методики технологічної підготовки, охорони праці та безпеки життєдіяльності Центральноукраїнського державного педагогічного університету імені Володимира Винниченка.

Наукові інтереси: теорія і методика професійної освіти.

\section{INFORMATION ABOUT THE AUTHOR}

PULIAK Olga Vasylivna - candidate of pedagogical sciences, docent, docent of department of theory and method of technological preparation, labour and safety of vital functions protection, professor of department of physics and method of its teaching of the Volodymyr Vynnychenko Central Ukrainian State Pedagogical University.

Circle of research interests: theory and methods of professional education.

Стаття надійшла до редакиії 20.11.2019 р. 